わが国においては，加速器に括けるトリチウムター ゲットや重水炣で 2 次的に発生するトリチウムの管理 経験を通じて，トリチウムに対する作業者の防護なら びにモニタリング技術ははぼ確立されてきた。

しかしながら，核融合研究に和けるように大量のト リチウムガス $\left(\mathrm{T}_{2}\right)$ が取り扱われる場合には、トリチウ ムガスの捕集など高濃度トリチウムの安全取扱い技街 やトリチウムの性状とくにガスと酸化物との举動の 相違を考虑した被懪評価やモニタリング技術の確立が 重要な課題になる。

本稿では，核融合に関連して，トリチウムを比較的 大量に，特にガス状で取り扱ら場合の環境への放出低 減技術，環境モニタリング技術ならびに被曝線量推定 技術の現状について述へる。なお，安全取扱い技術全 般について別に稆介した文献(1) と重複する部分のある ことを和断りする。

\section{I 、トリチウムの性自}

トリチウムは，物理的半減期約 12.3 年，比放射能 $9,600 \mathrm{Ci} / \mathrm{g}$ 低エネルギー $\beta$ 放射体(エネルギーは最大

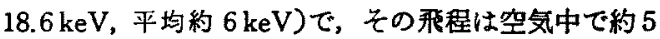

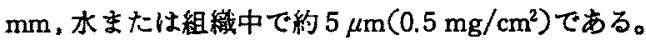
トリチウムの㻴境に括ける主な存在形態は，水素ガス $\left(\mathrm{T}_{2}, \mathrm{HT}\right.$ など) と酸化物 $\left(\mathrm{T}_{2} \mathrm{O}, \mathrm{HTO}\right.$ など)のほか，C H、厂よ゙有機物である(2)。環境に放出されたトリチウ ムガスは，最終的には大部分が酸化物に転換する(IIー 2 節参照)。

トリチウムの人体への影警の基本的事項は次のとお りである(3(d)。酸化物の場合は吸入トリチウムの98 99\%が体内に摄取されるが，木素がスが昅入により体 内に取り込まれる割合は，酸化物の場合の約 $1 / 15,000$ である。な敃酸化物は皮庙からの浸透によってる体内
に取り込まれる。トリチウム水蒸気の体表面(標弾人 体の表面榬 $\left.2 \mathrm{~m}^{2}\right)$ からの摄取量は吸入掑取量とほほ同一 になる。また,トリチウム水(HTO)が皮唐から体内に 浸透する割合は $0.03 \sim 0.06 \mathrm{mg} / \mathrm{cm}^{2} \cdot \min$ と報告されて いる(3)。したがって，空気中トリチウムが酸化物の場 合は，吸入および皮届からの浸透による撕取のほか， 環境においては食物連鎖による経口摂取が問題となる が，水素ガスとして存在する場合は，内部被懪は無視 でき，放出 $\beta$ 楾による皮有または眠の被嚗が問題にな るのみで，その危険度は酸化物の場合に比へて 2 桁以 上小さい。人体内に取り迅まれたトリチウムは，摄取 後短時間に大部分が皮の形で身体内に注は均等に分布

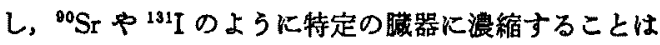
なく，その主要成分の生物学的半減期は 8〜12日であ る(4)。これらのトリチウムの特性に基ついて定められ たICRP 勧告の最大許容身体負荷量(MPBB) ${ }^{(5 \times)}$ と最

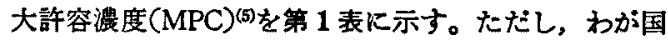
の法規では(MPC) 化物に対する值が定められている。

トリチウムの生物影響については，上記のほかいく つかの問題がありこれらの調查結果のまとめが多数 報告されている(4)が 。本稿では環境の線量評価に関 する生物影繁の主要な問題を最近の文城心から引用し 紹介する。

(1) 線質䋆数 $(Q F)$ : 1965年以前の ICRP 勧告では, $0.03 \mathrm{MeV}$ 以下の電子に対する $Q F=1.7$ とされ，第 1 表の(MPBB)および(MPC)はトリチウム $\beta$ 線の $Q F=$ 1.7として求められたるのである。ICRPはその後の生

Present Techniques for Control of Tritium Release and Environmental Monitoring in Fusion Research, Yoshikazu YosHIDA, Yuji NARUSE, Toshinori IIJIMA.

（1979年 2 月 5 日 受理） 
物学的効果の調査絬果からトリチウム $\beta$ 線の $Q F$ を 1 より大きくする特別な根抛はないとして、最近の钩告 (11) (12)では $Q F=1$ を採用している。ただし，一部の分 野でQF=2〜4を示唤する報告もある。

第1表トリチウムの最大許容身体鱼荷量 (MPBB) と最大部容灌度(MPC) (1)

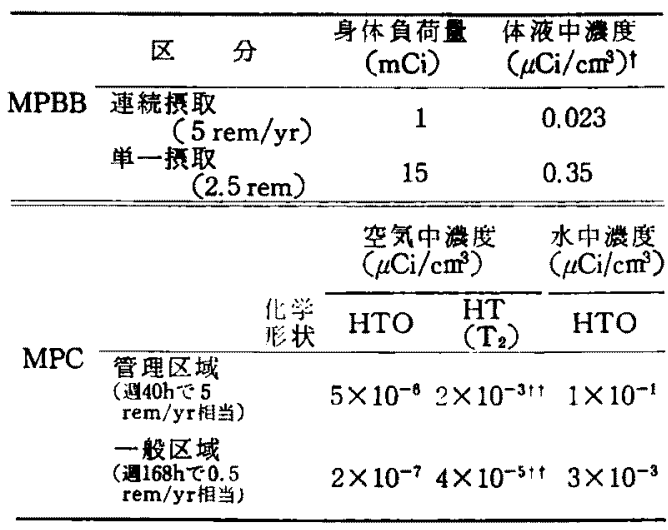

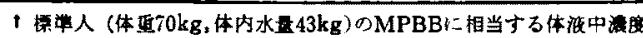

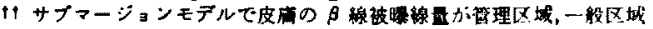
に対し，それそれ30と $3 \mathrm{rem} / \mathrm{y}$ とに相当する。

（2）有機物との結合による長半減期成分：体内に 取り込まれた HTOの一部は，組織の有機化合物に取 り込まれ，再交換または組織有機物の分解過程によ り，ふたたび体液の HTO となって排出される。した がって，体内に取り込まれた HTOは前述の10日前後 の半減期で非出されるほかに，一部は体内に保留さ れてゆっくりと排出される成分(生物学的半娍期か 30 〜40日と300〜600日の2成分)があるが，後者の割合 は極めて小さくその線量寄与恮線量の20\%以下であ る。

（3）生体重要分子への取り达及効果：体内に取り 込まれたトりチゥムの一部は RNAやDNA分子中に 取り込まれ，身体的および遗公的影製を与える可能性 が考えられるが，現在までの多数の報告では，その奻 果が特に危険性を増すことは示されていない。

(4) 核变換(Transmutation)効果：細胞分子に結合 したトリチウムの壊変によってH原子が He 原子に変 ることによって生ずる核变換効果は，細胞レベルおよ。 び動物実験結果から，放射線の効果に比へて重要では ないことがわかっている。

以上が現在の結論と考えてよいが，今後低レベルト リチウムの生物影留に関する研究をさらに進めること の必要性指摘されている。

(吉田涪和)

\section{I . トリチウムの放出低減化技術}

核能合姖においてはDーT系の然料を用いるため、ト リチゥムの製造システム，炬に和ける然料給排気ンス テム(トリチウム精旼・眛環システム)およびフランケ ット処理システム,トリチウム廃萧物処理システム, ト リチウム格納システム等のトリチウム然料サイクル技 術の確立と，それを支える幅広い工学基礎研究が必要 になる。米国においては，Mound Lab., LASL, LL L, Sandia Lab. などの研究機関に肪いて、トリチム

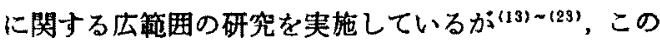
5ち Mound Lab. の TECL (Tritium Effluent Control Laboratory)は (13)，小規模の施設ながらトリチウムに 係わる安全対策と放出低減化技術が請じられており， 今後わが国において核蟞合関連のトリチウム研究施設 の建設を進めるとき，最す参考となるすのと考えられ る。そこで，本章ではTECLを中心にして，トリチウ ム研究施設におけるトリチウム除去システムと，笔策 物処理システムとについて述べトリチウム取扱いに 関する基本事項を明らかにする。

\section{TECL の概要(13) (13)}

Mound Lab. では大量のトリチウムを取り敖ってい るが，当初の設計・渾転には，作業者の安全確保と施設 の境界において濃度基準(Radioactivity Concentration Guide, RCG)を满足すへくく，排気系の空気流量をでき るだけ大きくして希釈効果を上げる上ら考虑が払われ ていた。しかし，1970年の ALAP(As low as practicable)の考之方に基つき，対象となる濃度点を施設の 境界からスタックの放出口に変更し，スタックにおけ る濃度を RCGの10\%以下となるようにするため，檑 種の改造および装置の新設を行なった。この結果、ト リチゥムの放出量は，第 1 図に示すよ5に低下した (1980年の月推健は $5,000 \mathrm{Ci} / \mathrm{yr}$ である)。

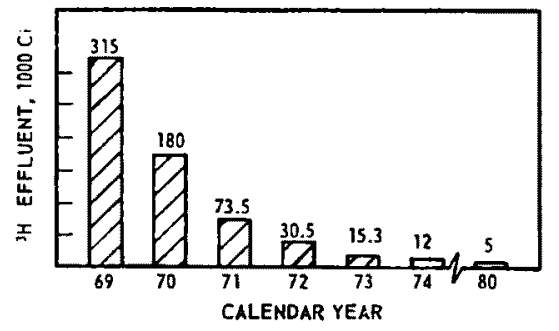

第 1 图 Mound Lab.におけるトリチウム 放出低減化の実続と目䅺值(19)

TECL は ${ }^{(13)}$ このような背等のもとに, 将来の㤥融 合哣のトリチウム格納システムを念頭におき，恣圈お 
よび設備から漏沂または排出されるトリチウムを捕集 し，大気中への放出を RCG の $10 \%$ 以下に保持するた めの技術を開発することを目的として建設された小型 の実験施設である。本施設は，他の大量トリチウム取 扱施設から隔離され，トリチウム放出を制御し，イン ヘンントリー管理が確実になされるよ5配麀されてい る。

第 2 図は，TECL のレイアウトを示したすのであ る。本施設は実験室, 装置室, 制御室および更衣室から 構成されており，トリチウムの取扱い量は最大 $3 \times$ $10^{4} \mathrm{Ci}$ である。

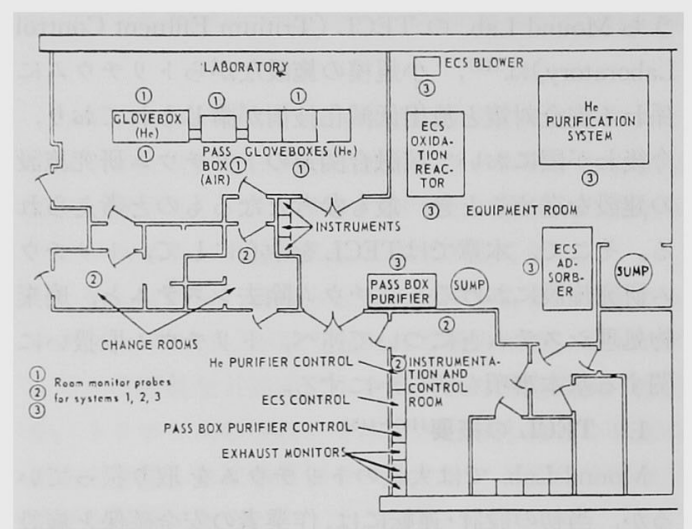

第 2 図 Mound Lab.のトリチウム取扱い施設

$\left(\mathrm{TECL} \text {, 取扱い量 } \sim 3 \times 10^{4} \mathrm{Ci}\right)^{(13)}$

実験室(約 $\left.60 \mathrm{~m}^{2}\right)$ には，写真 1 に示すように，4台の グローブボックスと 1 台のパスボックスが配置されて いる。大型のグローブボックスには水素同位体分離用
の深冷分離装埴が，小型の 3 台のグローブボックスに は小規模の実験装置が設直されている。グロープボッ クス雾囲気ガスとしては He を使用し，操作王力は 1 in. 水柱程度の負圧である。パスボックスは，実験器 具や材料の搬出入または除染用として使用され，雾囲 気ガスとして空気が用いられている。

装置室 (約 $\left.100 \mathrm{~m}^{2}\right)$ には，3 種類のトリチウム除去シ ステムが設置されている。GADS (Glovebox Atmosphere Detritiation System)はグローブポックス雾团気 である Heからトリチウムおよび混入微量空気を除去 するためのるのであり, ADS(Air Detritiation System) はパスボックス雷囲気である空気からトリチウムを除 去するためのあのである。また，ECS (Emergency Containment System) は異常時に作業エリアに漏洩し たトリチウムを捕集するための装直である。以上のよ うに，平常時および異常時を対象としたトリチウム除 去システムが完備され，作業者の被曝防止および環境 への放出低減化が図られている。

このほか, Mound Lab. では共通設備として，真空 排気装置からの排ガス(有機物蒸気を含む)，不活性雾 囲気ガス精製システムおよびパスボックスからの污染 ガス, 除染や保守作業のときに発生する排ガス(溶媒蒸 気等)など種々の装置の排ガスからトりチウムを除去 して環境へのトリチウム放出を低減化させることを目 的とした ERS (Effluent Removal System)を設置して いる(14)。このシステムは，広濃度範囲のHT, HTOを 捕集でき,比較的多量の水分, 油および有機物が含まれ ていても対処できることが要求されるので，多目的シ

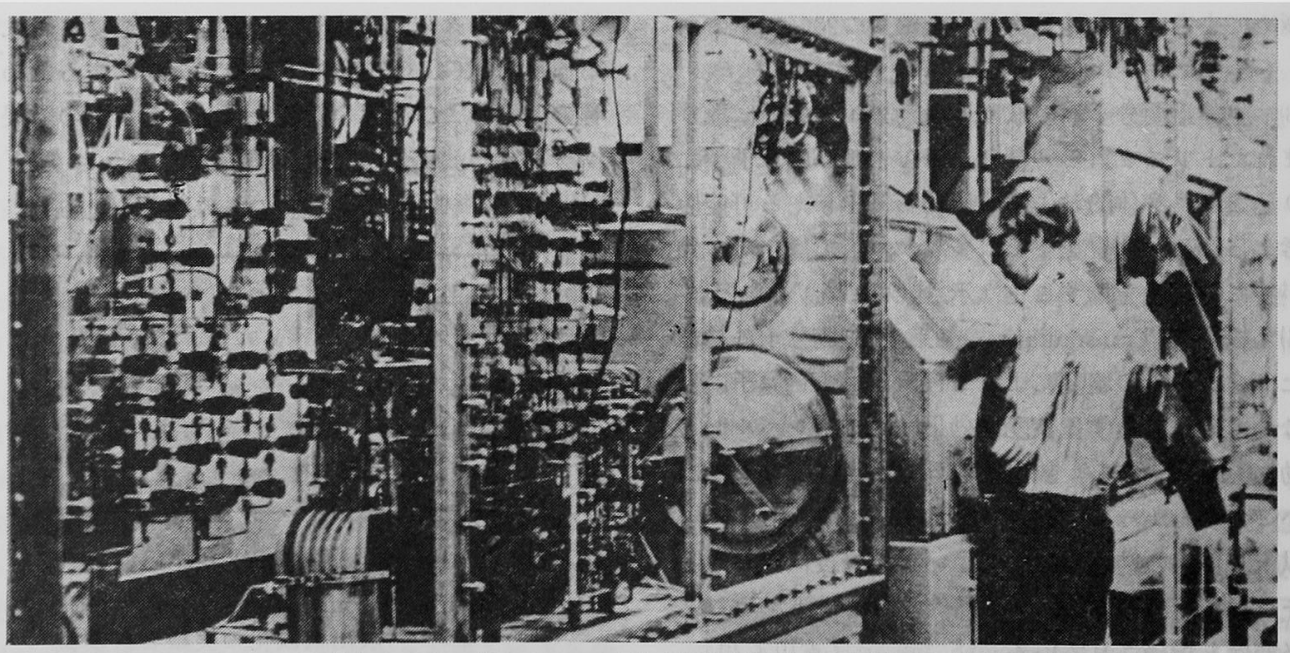

手前のダローブボックスには水素同位体分離用の滐冷分離装置が設置されている。 中央の実験中の小型ボックスけパスボックスである。

写真 1 TECL 内のグローブボックス 
ステムとなり，装監は複雑で大型となる。

制御室(約 $30 \mathrm{~m}^{2}$ )には,トリチウム除去システムの制 御計，モニタ類, 整報システムが設けられている。異常 時には，制御室においてトリチウム除去システムを遠 隔操作により運転できる。

室の換気は, コールド区域 $\rightarrow$ 実験室 $\rightarrow$ 装置室の方向 に流れ，各室間の差圧は0.1 Torr 程度である。実験室， 装置室の床面, 壁面, 天井は通常のホット実験室と同じ であり、トリチウムに対して特別の考虑は払われてい ない。

トリチウムの取扱いには，前述したように，グロー ブボックスが用いられる。グローブボックスの材料と しては通常，本体にはステンレス鋼，操作面(空)には 強化ガラス,グローブにはネオプレン,ブチルゴムが採 用されている。グローブボックス製作上の問題である 漏洩量については，1 測定点で $10^{-8} \sim 10^{-9} \mathrm{~atm} \cdot \mathrm{cc} / \mathrm{s}, 1$ 台当りで $10^{-5} \sim 10^{-6} \mathrm{~atm} \cdot \mathrm{cc} / \mathrm{s}$ といら報告もあるが(15)， これは構成材料(特にグローブ材)からの透過量とのハ: ランスを考慮して決定すべきである。第 3 図は，グ ローブ材として使用される各種ゴムについてトリチウ ムの透過速度を示したものである(16)。これより， HTO の透過速度は HTよりもほぼ 2 桁大きく，材料 としてはブチルゴムが優れていることがわかる。この ようなことを考慮して, Mound Lab. では, ブチルゴ

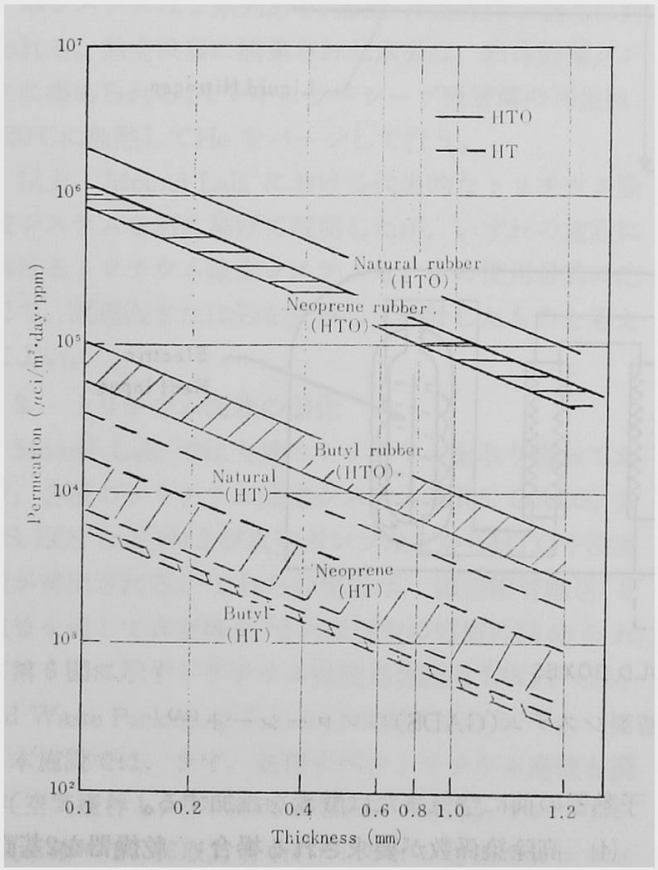

第 3 図各種グローブ材のトリチウム透過速度 (16)
ムを主体としたグローブを採用している。グローブボ ックスの取扱いに関しては，グロープポートに密閉用 カバーを設け，使用に先立ちグローブを透過したトリ チウムを真空排気したり，グローブボックス作業で使 用する保護用ゴム手袋を適当な間隔で交換して，被嚗 を防止することが必要である(18)(19)。

2. トリチウム除去システム

トリチウム除去システムにおけるトリチウムの捕集 の原理としては，一般に，(A)トリチウムガスを酸化し て水分の形でモレキニラーシーブなどに吸着させる方

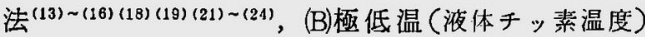
で不純物ガス(トリチウムを含む)をモレキュラーシー ブなどに吸着させる方法 ${ }^{(13)}$ が採用されている。

第 4 図は，(A)の原理に基つくくトチウム除去システ ムとして, Mound Lab. の ADSのフローシートを示 したものである(13)。パスボックスからのトリチウムガ スを含む空気は，フィルタを通りブロフーにより本シ ステムに供給される。まず，ガスーガスの熱交换器に より予熱されて触媒反応器に入る。触媒反応器は, ヒ 一ターにより $150 \sim 540^{\circ} \mathrm{C}$ の温度に加熱される(設定温 度は炭化水觉の有無による)。触媒としては， Engel hard No. A 16648(DEOXO 触媒)が用いられている。 ここで，トリチウムは空気中の酸素と反応して HTO (水蒸気)となる。触媒反応器を出た HTO を含む空気 は, 熱交換器で室温まで冷やされてブロアーにより乾 燥器に送られる。乾燥器にはモレキュラーシーブLinde type 13X が充嫃されており，ここで空気中の HTOが 除去される。ADS で処理された空気は再びパスボッ クスに戻される。

本システムの不純物除去仕様は，次のと扣りであ る。

\begin{tabular}{lcc}
\hline 不种物 & 入П濃度 $(\mathrm{ppm})$ & 出口濃㡲 $(\mathrm{ppm})$ \\
\hline $\mathrm{H}_{2} \mathrm{O}$ & 30,000 & 10 \\
$\mathrm{CH}_{4}$ & 1.0 & 0.001 \\
$\mathrm{C}_{3} \mathrm{H}_{8}$ & 1.0 & 0.001 \\
$\mathrm{H}_{2}\left(\mathrm{~T}_{2}\right)$ & 1.0 & 0.001 \\
\hline
\end{tabular}

すなわち，本システムが得られる除染係数は，炭化水 素扣よびトリチウムに対し1,000である。

以上は，最も基本となるプロセスについて述べたも のであるが，実際には各場合に応して次のような考虑 を払う必要がある(24)。

(1) 処理すべきガス中のトリチウムの化学形が水素 ガスの場合 : 舯媒反応器の操作温度は約 $180^{\circ} \mathrm{C}$ 程度 でよい。 


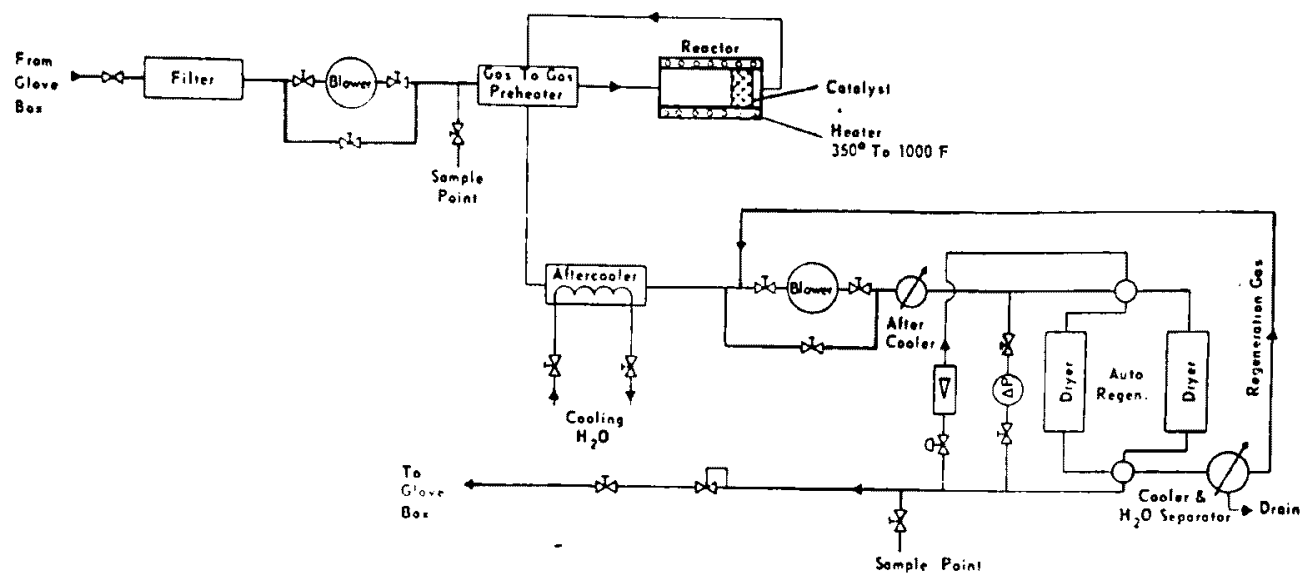

第 4 图 バスボックス严囲氛ガス精製システム(ADS)のフローシート (13)

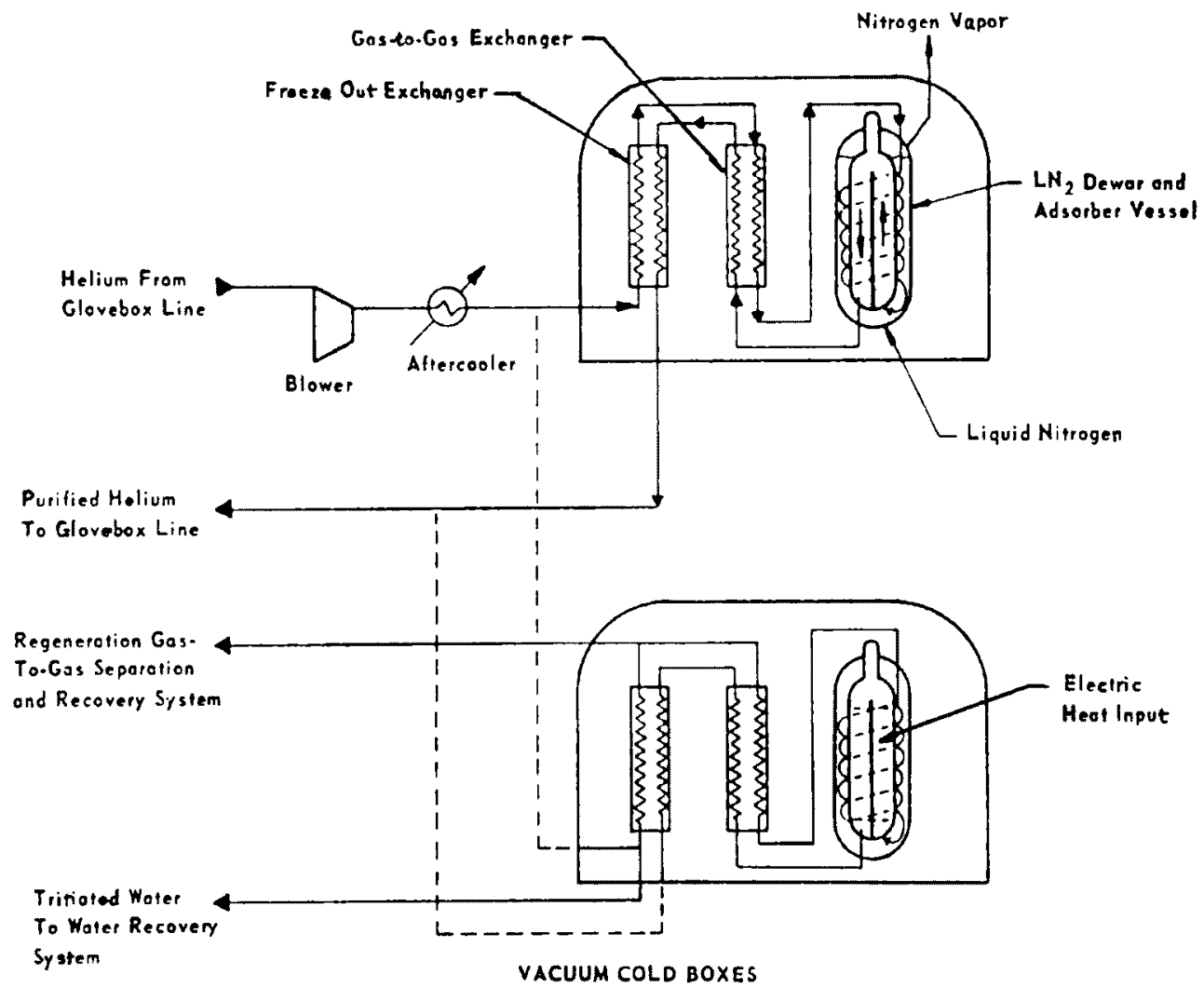

第 5 图 グロープボックス雾围気ガス精制システム(GADS)のフローシート(13)

（2）処理すべきガスに炭化水素を含む場合：触媒 予熱器の前に空気または酸素を添加する。 反応器の操作温度は約 $500^{\circ} \mathrm{C}$ 程度とする。

(3) 処理すべきガスが不活性ガス(Heなど)の場合:

（4）高除染係数が要求される場合：乾燥器を2基直 列に設け，その中間に水を添加する方式(Interstage 
Water Addition Swamping System)を採用する。

(5) 大量のトリチウムガスが実験室に漏出するとい う異常時に使用する場合：薂燥器にあらかじめ水分 を飽和させておき，H-T の同位体交換反応を利用す る。

（6）乾燥器を再生し繰り返し使用したい場合：循 環用ブロアー, 予熱器, 冷却器, 水分(HTO)トラップな どからなる再生システムを別に設固する。この場合に は，乾燥器は 2 系列設けることが望ましい。

第 5 図は，(B)の原理に基づくMound Lab.の GADS のフローシートを示したものである(13)。グローブボッ クスから排気された He は,ガスーガスの熱交換器(予 冷器)に導かれて冷却される。ここで, $\mathrm{He}$ 中のトリチウ ムを含む水蒸気は大部分除去される。ついで，液体チ ッ素で泠却されたモレキュラーシーブ吸着塔(Linde 5 $\mathrm{A}$ が $300 \mathrm{lb}$ 充塓されている)に入る。本システムの設 計条件は, $\mathrm{O}_{2}, \mathrm{~N}_{2}, \mathrm{H}_{2} \mathrm{O}, \mathrm{CO}_{2}, \mathrm{CmHn}, \mathrm{H}_{2}, \mathrm{~T}_{2}$ なとの不 純物について，出口濃度が 1 ppm以下になることであ る。特に水素同位体については,トリチウムを含めて 出口で $0.01 \mathrm{ppm}$ を超えないようにしている。モレキ ュラーシーブ吸着塔の操作条件は $77^{\circ} \mathrm{K}$, 大気圧付近で ある。な拉，本システムの主要部は，図に示されてい るように，断熱用のコールドボックス内に収納されて いる。

本システムは 2 系列あり,捕集-再生操作が交互に行 われる。熱交換器に捕集された水分は, 液体眝留タン クに集められる。モレキュラーシーブ吸着塔の再生は, $120^{\circ} \mathrm{CK}$ 加熱してHeをパージして行ら。

以上，Mound Lab. における代表的なトリチウム除 去システムを例に挙げて説明したが，いずれの施設に 护るトリチウム除去システムも，その使用目的に応 しで，原理(A)または(B)を変形して設計したものと考え てよい。

\section{3. トリチウム廃液の固化}

Mound Lab. では大量のトリチウムを取り报ってお り，各種のトリチウム除去システム(ERS，GADS，A DS, ECS など)㧊よび真空ポンプなどからHTOや油廃 液が排出される。これらの廃液は，直接配管輸送(2 重管を通して真空输送)または所定の容器に詰められ て第 6 図に示すトリチウム廃液処理施設 LWPF (Liquid Waste Packaging Facility)に搬入される(17)。

本施設では，まず，処理すべきトリチウム廃液を筧 汼(空気筧拌し，その排気は ERSで処理)，サンプリン グ(正確に $1 l$ 採取), 分析(インライン方式のカロリメ 一タで測定)し、トリチウム量を計量する。本分析法の

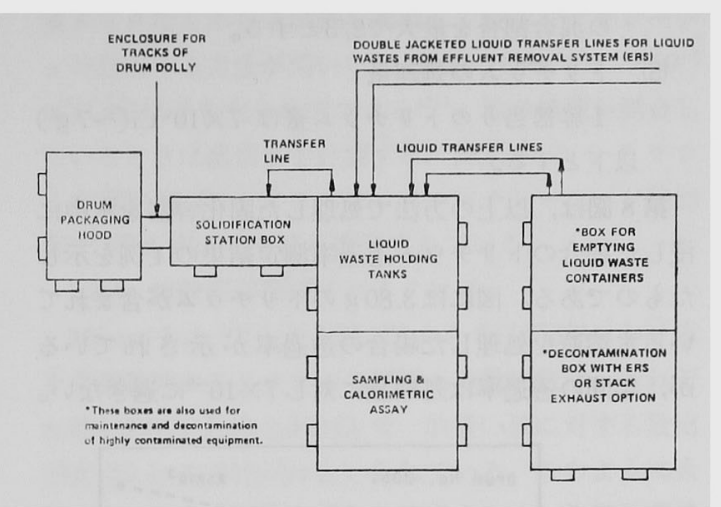

第 6 図トリチウム廃液処理施設

(LWPF)の配圆図 ${ }^{(17)}$

精度は土 $1 \mathrm{~mW}$ トリチウム最にして $3 \mathrm{mg}$ )である。 計量されたトリチウム廃液は，第 7 図に示す 3 重の容 器内で所定の固化剤と混合して固化する。

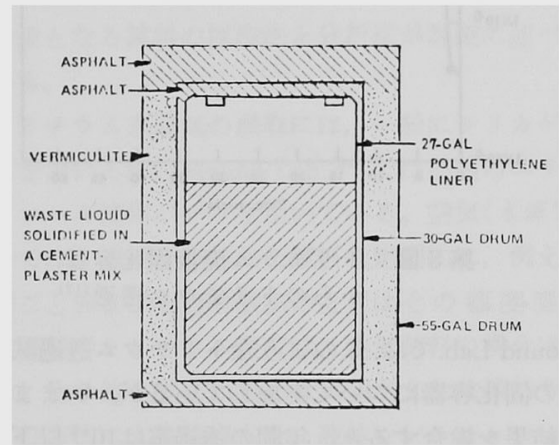

第 7 図トリチウム廃液の固化 と包装のための容器 ${ }^{(17)}$

トリチゥム廃液固化容器および固化剤の仕様は次の と拈りである。

(1) 固化容器

第 1 次容器：硬質のポリェチレン,ポリプロピレ ン(ないしは, 同等の耐食性, 耐衝整性をるつ材 料)製の気密容器で, 第 2 次容器 $(115 l)$ に密着 插入できる大きさの容器 $(100 l)$ 。

第 2 次容器：アスファルトでコーティングされた

$115 l$ の鋼製の容器。

第 3 次容器： $210 l$ の鎡製の容器。

(2) 固 化 法 水溶液の処理：水溶液/(セメント+石言)の混合 割合(重聂)を最大で1/3とする。

オイルの処理：オイル/パーキュライトの混合 割合を最大て2/1とする。またはオイル/Absorbal 
の混合割合を最入で2/3とする。

(3) トリチウムの処理量

1 容器当りのトリチウム量は $7 \times 10^{4} \mathrm{Ci}(\sim 7 \mathrm{~g})$ 以下とする。

第 8 図は，以上の方法で処理した固化容器を水中に 浸した場合のトリチウム透過率測定結果の 1 例を示し たすのである。図には $3.80 \mathrm{~g}$ のトチウムが含まれて いる水溶液を処理した場合の透過率が示されている が，年間の透過率は処理量に対し $7 \times 10^{-8}$ に過ぎない。

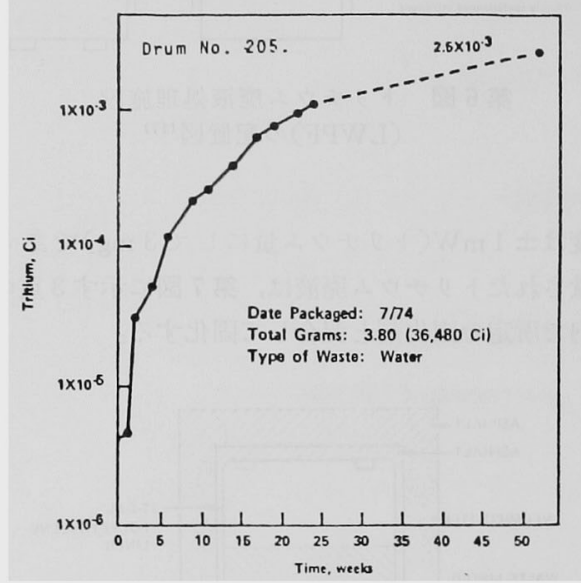

第 8 図トリチウム廃液固化容器 からのトリチウム透過 ${ }^{(17)}$

Mound Lab.では,このよらなトリチウム透過試験を 多数の固化容器について実施しているが，いままでの 测定結果を総合すると，年間の透過率は $10^{-6}$ 以下とい われている。

(成瀬雄二)

\section{III .トリチウムの環境管理}

\section{1. モニタリング}

トリチウムは前述のように，その放出 $\beta$ 線の飛程が 極めて短いので，その测定にはガス捕集型電離箱やガ スフローカウンタのように検出器内にトリチウムを 導入する方式，またはプラスチックや夜体シンチレー タのように直接接触する方式の検出器が用いられる。 また、トリチウムの測定方法については論文 ${ }^{(25) \sim(28)}$ 中 マニュアル(29)(30)などが多数発表されている。特に， NCRP レポート ${ }^{(26)}$ には, 各種の測定方法が検出感度順 にまとめられ，連続測定の可否など適用上の特徵が示 されている。本節では，比較的実用化されている測定 方法を中心に紹介する。

(1) 排気モニタリンク

空気中トリチウムの測定方法としては，(1) 試料空
気を検出器に值接導入して測定する方法, (2) 空気中 の水蒸気を捕集(トリチウムガスの場合は触媒などに より酸化後捕集)し，その捕集水中のトリチウム濃度 を計測することにより空気中トリチウム濃度を求める 方法の 2 つがある。これらの测定方法のらち，比較的 実用化されている方法とその主な特徽を第 2 表(1) に示 す。電離箱型モニタは,トリチウムの性状に関係なく 空気中の全トリチウム濃度を連続的に測定するすの で，排気中など空気中のトリチウム濃度の監視の基本 的測定器として広く用いられているが，第 2 表に示さ れる特徵のほか，高濃度トリチウム測定後の内部污染 によるメモリー効果などの欠点がある。外部放射線の 影響を除去するためには $\gamma$ 線補償型のるのが用いられ る。

第 2 表 空気中トリチウム漕度測定方法の比較(1)

\begin{tabular}{|c|c|c|c|}
\hline $\begin{array}{l}\text { 試料採取 } \\
\text { 方法 }\end{array}$ & 捕集材·計測器 & $\begin{array}{l}\text { 検出限界 } \\
\left(\mu \mathrm{Ci} / \mathrm{cm}^{3}\right)\end{array}$ & 備 \\
\hline \multicolumn{4}{|c|}{ 気体状で測定 } \\
\hline \multirow[t]{3}{*}{$\begin{array}{l}\text { 直接捕集 } \\
\text { 方法 }\end{array}$} & $\begin{array}{l}\text { ガス捕集用電離 } \\
\text { 箱(容皘 } 1 l \text { 程度) - } \\
\text { 振動容量型電位 } \\
\text { 計 }\end{array}$ & $2 \times 10^{-6}$ & $\begin{array}{l}\text { 半減期などの測定 } \\
\text { によ他の放射性 } \\
\text { 力スとの分激測定 } \\
\text { 可能 }\end{array}$ \\
\hline & 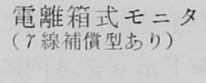 & $\stackrel{10^{-5}}{\sim} 10^{-6}$ & $\begin{array}{l}\text { 他の放射性カスと } \\
\text { の分離測定は困 } \\
\text { 難, 連続测定可能 }\end{array}$ \\
\hline & 比例計数管: & $\stackrel{10^{-6}}{\sim}{ }^{\sim} 10^{-7}$ & 同上 \\
\hline \multicolumn{4}{|c|}{ 液体状で測定 } \\
\hline $\begin{array}{l}\text { 冷却凝縮 } \\
\text { 捕集方法 }\end{array}$ & $\begin{array}{l}\text { 水蒸気凝縮 }(コ- \\
\text { ルトラン } \\
\text { S. } C^{\dagger \dagger}\end{array}$ & $10^{-9}$ & 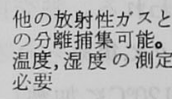 \\
\hline $\begin{array}{l}\text { 固体捕集 } \\
\text { 方法梓 }\end{array}$ & $\begin{array}{l}\text { モレュュラーシ } \\
\text { ーブ, シリカゲ } \\
\text { ル-L.S.C }\end{array}$ & $10^{-9}$ & 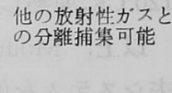 \\
\hline $\begin{array}{l}\text { 夜体捕集 } \\
\text { 方法†t广 }\end{array}$ & $\begin{array}{l}\text { 水バブラ-L.S. } \\
\text { C. }{ }^{\dagger}\end{array}$ & $10^{-6}$ & 同上 \\
\hline
\end{tabular}

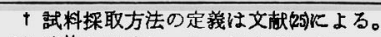

†夜体シンチレーションカウンタ

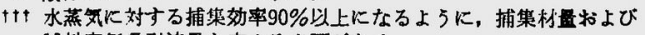
試料空気吸引流典を定める必要がある。

電離箱型モニタの検出感度を $1 \times 10^{-6} \mu \mathrm{Ci} / \mathrm{cm}^{3}$ 以下ま で向上させるためには，次の方法が用いられる(13)(15)。

(1) 大容積 $(20 \sim 50 l$ 程度)の電離箱を用いる。

（2）低線量率の場所においても $\gamma$ 線補償型電離箱を 用いて外部放射線の影響を補償する。

(3) メモリー効果を低減する方策を講ずる。そのた め 1 日 1 回程度定期的(高漕度のトリチウムが通 過したときにはその都度)にバルブの切換えなど により，乾蜗した清浄空気(できれば高温の空気) を電離箱に一定時間流通させることにより，トリ チウムによる内部污染を防止する。ほかに電離箱 
内面の金メッキも内部污染低隇に用いられてい る。

電離箱を用いて他の $\beta$ 核種を分離㨽定する方法とし て、トリチウム $\beta$ 線のみを透過しないような薄い壁で 隔離した同心円简型電蜼箱が開発されている(3)。 た，比例計数管を用いて $2 \times 10^{-8}$ 程度の低濃度まで测 定できるようにするため,ガードカウンタと逆同時計 数回路を付けた比例計数管(有感容皘 $2.27 l$ ) 式モ二タ が試作されている(13)。

第2表のらち, 空気中の水蒸気を捕集して計測を行う 方法は，水蒸気成分を(MPC)。の1/1,000以下の濃度ま で測定できるが，連続測定監視には不向きである。た だし，冷却疑縮方法または液体バブラ捕集方法とフン トラセン・フローセルまたは液体シンチレータ・フロー セルとを組み合わせることにより連続湘定を行うこと るできるが, その場合の空気中濃度の検出腿界濃度は， 非逨続湘定の場合に比べて $2 \sim 3$ 桁高くなる(26)。

大量のトリチムムガスを取り扱ら施設の排気モニタ リングに括いては，電離箱型モニタにより全トリチウ ムの濃度を連続監視するとともに，水蒸気成分を連稑 サンブリングして定期的に测定するのが一般的であ る。例として，Mound Lab.の TECL に抹ける排気モ ニタリング方式を第 9 図 ${ }^{(32)}$ 亿示す。この場合，液体心 ブラと贵金属触媒との組合せにより水蒸気とガス成分 が前段と後段のバブラにそれぞれ分離捕集され，一定 期間中のそれぞれの放出量が定量される。

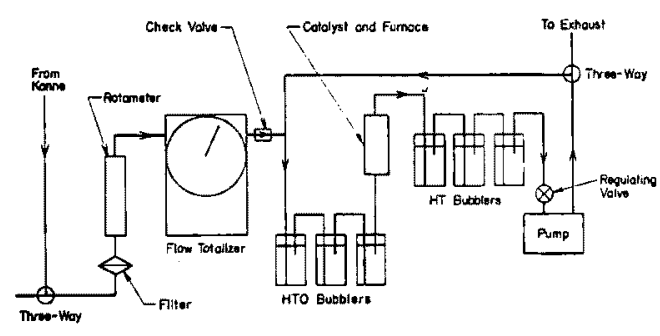

第9图トリチウムのガスと水蒸気成分 の分離捕集用サンブラ(32)

Mound Lab.に打いては，バブラ液には，サンプリン グ中の蒸発と谏結を防止するためにェチレン・グリコ 一ルが使用されている(33)(34)が，捕集原理は水バブラ と同様であって，上流側バブラ 2 段の捕集効果は $99 \%$ 以上と報告されている。また, バブラの代わりにシリカ ダルなどの捕集版を用いることもできる。

（2）排水モニタリンタ

排水中のトリチウムのモニタリンタには，一般に廃
液タンクなどから水試料を採取し，液体シンチレーシ ョン計湘する方法が用いられ，最近の技術では $1 \times 10^{-8}$ $\mu \mathrm{Ci} / \mathrm{cm}^{9}$ 以下を充分検出できる ${ }^{(35)}$ 。他の核種が混合し ているときは蒸留皮を計測する。排水中のトリチウ ムの連穁測定にプラスチックシンチレーション検出 器 (25) (36)を用いる方法が開発されている。

（3）施設周辺環境モニダリング

Mound Lab. ${ }^{(34)}$ と LASL ${ }^{(37)}$ からの 1976年における 平常稼動時のトリチウムの環境への放出量は，それぞ れ約 $6,000 \mathrm{Ci}$ と約 $2,000 \mathrm{Ci}$ で，取扱い量に対する放出 割合は0.1 0. 01\%/yr といわれている。このように大 量のトリチウムが取り报われる場合には，施設外環境 に怙けるトリチウムのモニタリングか必要になる。モ ニタリングの対象性，トリテウム水蒸気のほか，表面 水(河川水, 池水など), 地下水，土襄や農作物中のトリ チウム氷などである。

わが国で最近定められたトりチウム分析法 ${ }^{(30)}$ には， 原子力施設周辺環境におけるトリチウムモニタリンダ の対象となる試料の採取法と分析法が詳細に述べられ ている。

トリチウム水蒸気の採取には，一般にシリカゲル捕 集材を用いるが，Mound Lab. ${ }^{(34)}$ では前述のエチレン クリンール液体バブラを用いている。空気(水蒸気)に ついては，遧続採集された試料を定期的に，例えば2

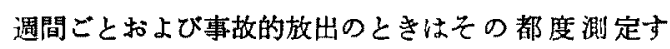
る。試料中トリチウム濃度は, 空気試料の場合は捕集 水を，その他の試料の場合は蒸留水または凍結中減圧 などの方法による抽出水を。淮体シンチレーション計 測して求める ${ }^{(26)(37) 。 ~}$

(吉田荡和)

\section{2. 㻴境線量の評価}

環境へ放出されたトリチウムが人間に放射線被嚗を もたらす経路(被懪経路)は他の放射性物質の場合と同 様であるが，第漳で紹介されているようなトリチウ ム特有の性質のために，被曝経路の重要性について異 なる点がいくつかある。特に,トリチウムの化学形態 によってその差異は大きい。トリチウムが大気中に放 出される場合には，まず払散中に放射される $\beta$ 線の皮 唐照射がある。この被曝経路による被晎線量は次式か ら推定することができる(38)。

$$
D=7.8 \times 10^{9} f_{s} E \bar{\chi}=4.4 \times 10^{7} f_{0} \bar{\chi}
$$

$$
\begin{aligned}
& \text { ここで，D：皮届線量 }(\mathrm{mrem} / \mathrm{yr}) \\
& f_{\mathrm{s}}: \text { " 皮青不感層の速蔽保数 }\left(10^{-4}\right. \text { 上り小さ } \\
& \text { い(ある万ら } \\
& E: 1 \text { 萠壤当り } \beta \text { 線として放出されるエネ }
\end{aligned}
$$


ルギーの平均优 $\left(5.7 \times 10^{-8}\right)(\mathrm{MeV} / \mathrm{dis})$

$\bar{\chi}:$ トリチゥムの扎表付近年间平均湍度 $\left(\mu \mathrm{Ci} / \mathrm{cm}^{3}\right)$

トリチウムガスは人体にはとんど取り込まれないが (芽I章)，酸化トリチゥム(HTO)の場合には呼吸摄 彼や経口摄取む考える必要がある。呼吸および皮虑浸 造による被曝線量は次のように得られる。

$$
D=k_{a} R \bar{\chi}
$$

$こ こ て ， D:$ 内部全身線㦸 $(\mathrm{mrem} / \mathrm{yr})$

$k_{\mathrm{a}}: 1 \mu \mathrm{Ci}$ の HTOを取り込んたこきい50

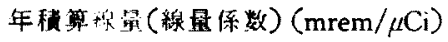

$R$ : 呼吸量 $\left(\mathrm{cm}^{3} / \mathrm{yr}\right)$

また，程口摄取では

$$
D=k_{0} W \Phi \bar{\chi}
$$

ここで，D：注目する食物（颠料水，牛乳含めて） の摄取に上る全身線量 (mrem/yr)

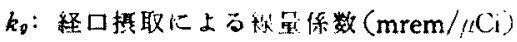

$W:$ 食物掫取量 $(\mathrm{g} / \mathrm{yr}, l / \mathrm{yr})$

$\phi:$ 人気中の HTOの其物への传行倸数 $\left(\mathrm{cm}^{3} / \mathrm{g}, \mathrm{cm}^{3} / l\right)$

Anspaugh らはHTO の植物への移行に関する研究 ふレビニーして，次のモデルを提唱した

$$
C=0.5 \bar{\chi} / H
$$

$$
\begin{aligned}
& \Xi こ \tau ， C \text { : 植物水召 } 1 \mathrm{~g} \text { 中の HTO 里 }(\mu \mathrm{Ci} / \mathrm{g}) \\
& H \text { : 紸效湿度 }\left(\mathrm{g} / \mathrm{cm}^{3}\right) \\
& \text { 0.5: 大気水分中 HTOの植物水分中一移行 } \\
& \text { ナる゙割合 }
\end{aligned}
$$

Morley らは，HTOの連続放出時では人間が摄取す る水分中の浱度は大気水分中の濃度と等しいと考え た (40)。また Baker らは，倛物中のトリチウムー水丵比 $(\mathrm{T} / \mathrm{H})$ は大気水分中の $\mathrm{T} / \mathrm{H}$ に等しいと想定した ${ }^{(41)}$ 。

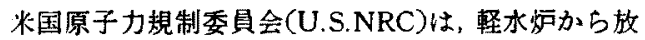
出されるHTO の莱菜や牛乳への移行を Anspaugh Б のモデルを用いて，次のように推定した ${ }^{(12)}$ 。

$$
\begin{aligned}
& C_{\mathrm{v}}=0.75 \mathrm{C} \\
& C_{m}=0.75 \mathrm{CM}_{c} F_{2 n}
\end{aligned}
$$

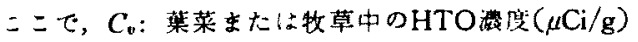

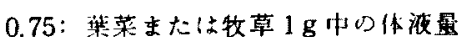

$C_{m}:$ 牛乳中の $\mathrm{HTO}$ 浝 $(\mu \mathrm{Ci} / l)$

$M_{\mathrm{c}}$ : 乳牛の牧草摄取量 $(\mathrm{g} / \mathrm{d})$

$F_{m}:$ HTO $1 \mu \mathrm{Ci} / \mathrm{d}$ 摄取率のときの牛乳中 機就 $(\mathrm{d} / l)$

これら $C_{v}, C_{m}$ をかが国の線量評価指針(43) のモデル
に用いれば（３）式の $\Phi$ はそれぞれ次のようになる。

$$
\begin{aligned}
& \text { 葉莱摄取 } \Phi=C_{v} f_{\imath} f_{m} f_{\iota} \\
& \text { 牛乳摄取 } \Phi=C_{m} f_{\imath} f_{m} f_{c}
\end{aligned}
$$

ここで， $f_{\imath}:$ HTOが移行した菓菜，牛乳の摄取 期間の作間制合

$f_{m}$ ：行場希彩割合

$f_{\&}$ : 調理時 HTO 残留割合

$f_{\mathrm{c}}$ : HTOの減少名桨した補正係数

かが国の主全である米類についても(4)，(5)式が 適用できれば， Фは次のようになる。

$$
\Phi=f_{m} C_{v}\left(1-e^{-\lambda_{t} / T}\right) / T \lambda_{e s}
$$

ここて， $\lambda_{e f}$ ：掑取まての HTO 隇少承 $\left(\mathrm{d}^{-1}\right)$ $T=365$ 日

(1)〜 (3)式をまとめると $D=A \bar{\chi}$ と表わせる。そ してどの被嚗経路が重要かはこれらAの比較から理解 されよう。関連バラメータに第3 表の值を用いると第 4表のようなムが得られるが，呼吸経路が最重要とい える。葉莱や牛乳摄取経路の奇与は呼吸経路より1标 小さい。この点は他の放射性物質の場合と巽なるとこ ろである。米類の揸取経路が比較的大きな奇与をする

\begin{tabular}{|c|c|c|c|}
\hline ハララメータ & 使用した值 & 谋考 & 文献 \\
\hline 楾量係数 $k_{a}(\mathrm{mrem} / \mu \mathrm{Ci})$ & 0.25 & 成人の全身 & (5) \\
\hline 線最係数 $k_{0}(\mathrm{mrem} / \mu \mathrm{Ci})$ & 0.13 & $\prime \prime$ & (5) \\
\hline 呼吸星 $R\left(\mathrm{~cm}^{3} / \mathrm{yr}\right)$ & $7.3 \times 10^{8}$ & 成人 & $(5),(43$ \\
\hline 釈対湿度 $H\left(\mathrm{~g} / \mathrm{cm}^{3}\right)$ & $1 \times 10^{-5}$ & $\begin{array}{l}\text { 大気温度 } 20^{\circ} \\
\text { 相対湿度70\% }\end{array}$ & \\
\hline 乳牛の牧草提取量 $M_{c}(\mathrm{~g} / \mathrm{d})$ & $5 \times 10^{4}$ & & (42) \\
\hline 牛乳人の移行率 $F_{n}(\mathrm{~d} / l)$ & $1 \times 10^{-2}$ & & 142 \\
\hline $\begin{array}{r}\text { 米数椇取まで娍少率 } \\
\lambda_{e}\left(\mathrm{~d}^{-1}\right)\end{array}$ & 0 & 仮 定 & \\
\hline 葉菜揸取量 $W(\mathrm{~g} / \mathrm{yr})$ & $3.65 \times 10^{4}$ & 成人 & \\
\hline 仁乳撰取量 $W(l / \mathrm{yr})$ & 73 & $\prime \prime$ & (43) \\
\hline 米数掑取助 $W(\mathrm{~g} / \mathrm{yr})$ & $9 \times 10^{4}$ & $\begin{array}{l}\text { 1974年度 } \\
\text { 全国平均 }\end{array}$ & \\
\hline
\end{tabular}
ように見えるか，矢際には刈取りから摄取までのトり チウムの減少があり，寄与は小さいのではなからう か。しかし，定量的な判断のためにはさらに研究が必 要である。他の战物摂取経路については移行モデルな との開発は必要であろらか，移行過程に蛅いてトりチ

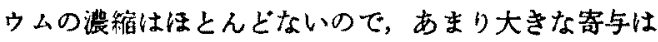
ないと想像される。欲料搷取経路については，放出 されるトリチウムの実際の移行過程を考察する必要が あろら。

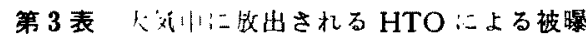
楾量の部算に用いたバムー夕の倠 
第4表 大筑中に放出されるトリチウムに 上る被暴線量の被踶経路別比软

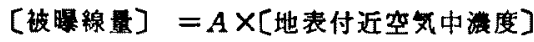

\begin{tabular}{|c|c|c|c|}
\hline 玻䀧程路 & $A\left(\frac{\mathrm{mrem} / \mathrm{yr}}{\mu \mathrm{Ci} / \mathrm{cm}^{3}}\right)$ & 被懪噳器 & 備 考 \\
\hline$\beta$ 楾外部被懪 & $4 \times 10^{7} f_{c} t^{t}$ & 皮店 & $f_{*}<10^{-4}$ \\
\hline 呼吸掑取 & $2 \times 10^{8}$ & 全 身 & \\
\hline 葉菜損取 & $9 \times 10^{7}$ & 全 身 & \\
\hline 牛乳摄取 & $9 \times 10^{7}$ & 全 身 & \\
\hline 米類摄取 & $4 \times 10^{8} f^{1 \dagger}$ & 全身 & $f_{e t}=$ ? \\
\hline
\end{tabular}

液体庭亲物中のトリチウムはすべて HTO と考えら れ，魚類などの摄取による取込みに注目すればよい。 さらに，魚類などのトリチウム濃繀比はほとんど1と 考えられるので，全身線量 $D(\mathrm{mrem} / \mathrm{yr})$ は简単に次の よらに推定できる。

$$
D=k_{0} \bar{C}_{w} \sum_{i} W_{t}
$$

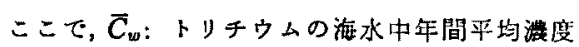
$(\mu \mathrm{Ci} / \mathrm{g})$

$W_{\mathfrak{l}}$ : 海産物 $i$ の年間摄取量 $(\mathrm{g} / \mathrm{yr})$

$k_{\sigma}:$ dose factor

トリチウムガスが大気中に放出された揚合，ての払 散中に僅かながら HTOに転换して行くことが知られ ている。しかし，転換の様子についてはいまた明確で はない。最近Burgerはトリチウムの大気中における 反応に開する研究をレビューし(2), トリチウムガスの $\mathrm{H}_{2} \mathrm{O}$ への直換や酸化による $\mathrm{HTO}$ ○の転换は触媒がな ければきわめて小さいこと，光化学的效果が支配的て あり，さらに長期間にはバクテリアの作用も重要とみ られることを指摘している。Yang らは50〜 700 $\mu \mathrm{Ci} / \mathrm{cm}^{3}$ のトリチウムガスについて実験したが、トリチウムガ スの $\beta$ 線により発生するHTOの濃度変化が次のよら に与えられることを見出した(45)。

$$
d C / d t=1.7 \times 10^{-3} C_{0}^{2}
$$

ここで, $C_{0}: \mathrm{T}_{2}$ の初期源度 $(\mathrm{Ci} / l)$

Burger はこの成係が $C_{0} \approx 10^{-3} \mathrm{Ci} / l$ まで成立すると 仮定して転换率を約 $0.004 \% / \mathrm{d}$ と見積った (Burgerは この程度の算度までは $\beta$ 線の転换作用が可能と考えて

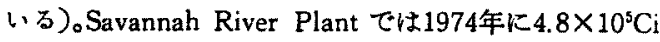
のトリチウムガスを放出する事故があったが，約 5 時間後に環境中で $0.2 \%$ HTOが測定された(46)。 Burgerはこれらのレビューにより，枟煥率を決定する には充分情報が得られていないが $1 \%$ 少以下であろ

\section{らと推定している。}

Sutra-Fourcade は 50〜 $700 \mathrm{Cj} / \mathrm{m}^{3}$ のトリチウムガス の酸化物への枟換について次のよらな転換俰数を得 $\star^{(47) 。}$

酸化: $K\left(\mathrm{~m}^{3} / \mathrm{Ci} \cdot \mathrm{s}\right)=1.72 \times 10^{-10}($ 乾燥空気中 $K(" \prime)=3.3 \times 10^{-10}$ (乾燥酸素中)

同位体交换: $K(\prime \prime)=4.63 \times 10^{-10}$ (水分含有空氮中) Ballereauはトリチウム転換に関する研究のレビュー の中で上記の結果を引用し，転換事が $0.2 \sim 2.8 \% / \mathrm{d}$ と なることを示している(48)。

次に，転換率と被曝線量との関係を考察してみよ 5。トリチウムガスの事故的な大睹放出を想定する。 転换率を $\alpha\left(\mathrm{d}^{-1}\right)$ とし，払散中の減衰や生成される醉 化トリチウムの地表沈等を無視すると，拡散中のトリ チウムガスの濃度と，生成されるHTO の濃度は次の ように表わされる。

$$
\begin{aligned}
& \left.\begin{array}{l}
\chi_{\mathrm{HT}}=Q_{\mathrm{HT}} e^{-(\alpha / u) \times} \chi_{0} \\
\chi_{\mathrm{HTO}}=Q_{\mathrm{HT}}\left(1-e^{-(\alpha / u) x}\right) \chi_{0}
\end{array}\right\}
\end{aligned}
$$

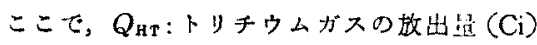

$$
\begin{aligned}
& u \text { : 風速 }(\mathrm{m} / \mathrm{d}) \\
& x \text { : 林出源加らの拡散距蜼 }(\mathrm{m}) \\
& \chi_{0} \text { : 国の公象指釬 }{ }^{(49)} \text { に定義される相対 } \\
& \text { 濃度 }\left(\mathrm{h} / \mathrm{m}^{3}\right)
\end{aligned}
$$

HTO の許容濃度が HT の1/200(第 1 菽)であるこ とに注目して，次の比を考える。

$$
R=200 \chi_{\mathrm{HTO}} /\left(\chi_{\mathrm{HT}}\right)_{\max }
$$

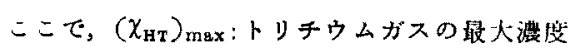

$\alpha=1^{\circ} \circ / \mathrm{d}, u=1 \mathrm{~m} / \mathrm{s}\left(=8.6 \times 10^{4} \mathrm{~m} / \mathrm{d}\right), \chi_{0}$ に妾象指 竍 ${ }^{(49)}$ の抁散式を使う上，放出高が $200 \mathrm{~m}$ 程度以下では 常に $R<1$ となる。実際にはHTO の地表沈着により 稙。はさらに小さくなるので，転換率が1％。/d程

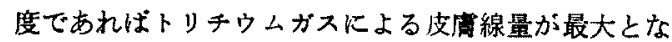

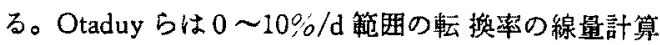
への影整を考察している(50)。

（11）式から理解されるよ5に，転换率が1.0/d の場 合には約500日で，また 10\%/dの場合には約50日でト リチウムガスの99\%が HTOに枟換される。したがっ て，地球規模の放射線被懪を考劣るときには，すべて HTO とみなす必要がある。

(飯崲敏哲)

本稿では、トリチウムの放出低減および琵境管理の 技術の現状を紹介したが，今後研究閒発が望まれる重 要な課題として，低濃度トリチウムを対象とする除去 
システムの実規模での性能向上，トリチウム廢莱物の 処理，処分，保管技術の開発，トリチウムガスの㜊境中 挙動(特に HTO 一の枟換)の解明などが考えられる。

\section{一弆考文献—}

(1) 吉田芳和, 成瀨雄二：Radioisotopes，27，160（1978）

(2) BERGER, L.L.: $B N W L-2113$, (1976).

(3) Pinson, E.A., it al.: J, Appl. Physiol., 10, 108 (1957).

(4) 秋田康一：原子力工業, 21[8]，14 (1975)

（5）日本アイソトープ拹全： ICRP Publ, 2，(1960).

(6) 同 上: ICRP Publ. 10, (1970).

(7) Bond, V.P.: Proc. Symp. Environmental Aspects of Nuclear Power Stations, p. 287 (1971), IAEA.

8) ElWood, J.IV.: Nucl. Safety, 12, 326 (1971).

(9) Strand, J.A., Thompson, R.C.: BNWL-2022, (1976).

(10) POHWER, P.S., WiLcox, W.H.: Nucl. Safety, 17, 216 (1976).

(11) ICRP: Health Phys., 17, 389 (1969).

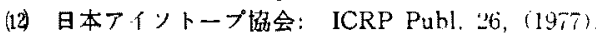

(13) Kershner, C.J., Bixel, J.C.: ML.M-2169 (OP), (1974).

(14) Rhinehammer, T.B., LAmberger, P.H.: $23 r d$ Conf. Remote Systems Technology, p. 94 (1975).

(15) iden: WASH-1269, (1973).

(16) WittenberG, L.J., it al.: Conf-760935-P4, 1339 $(19.6)$

(17) Mershad, E.A., et al.: Niul. Technol., 32, 53 (1977)

(18) CARSTENS, D.H.W.: 前 出 (14), p. 9.4

(19) ANDERSON, J.L., it al.: 同 上, p. 77 .

(20) LASL Group H-3: LA-6307-C, (1975).

(21) A.NDERSON, J.L., SHERMAN, R.H.: LA-6855-P, (1977).
(2) ANDERSON, G.W., et al.: SAND-76-8053, (1976)

(23) Collins, M.F., Terry, P.L.: Management of LowLevel Radioactive Symposium, (1977).

(24) SHER WOOD, A.E.: UCRL-78173, (1976).

(25) BUdnitz, R.J.: Health Phys., 26, 165 (1974).

(26) NCRP Rep. No. 47, (1976).

(27) SHANK, K.E., EASTERLY, C.E.: ORNL/TM-5344, (1976)

(28) 穴沢 豎, 他: 保键物理, 7, 27 (1972).

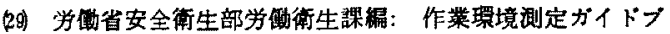

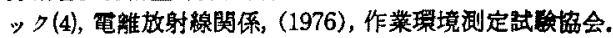

(30) 科学技術庁：トリチウム分析法，(1978）。

(31) JALBERT, R.A.: 前

(34) Bishop, C.T.: Personal Communication, (1977).

(33) SHEEHAN, W.E., et al: MLM-2205, (1975).

(34) FARMER, B.M., et al.: MLM-2416, (1977).

(35) IWAKURA, T., et al.: IAEA-SM-232, (1978).

(36) Muramatsu, M., et al.: Nucl. Instrum. Methods, 54, 325 (1967).

(97) Environmental Studies Group: $L A-6801-M S$, (1977)

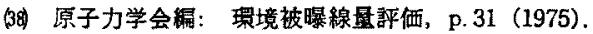

(38) ANspaugh, L.R., ct al.: UCRL-73195, Rev. 1, (1972).

(40) MORLey, F., Kennedy, J.W.: BNES Conf. Nuclear Fusion Reactor, p. 54 (1960)

(41) BAKER, D.A., SOLDAT, J.K.: BNWL-2020, (1976).

(42) U.S.NRC: Regulatory Guide 1.109, (1977).

(43) 原子力委夏会：発電用轻水型原子师施設周辺の線量目標 值に対する評洒指針，(1976).

(44) 飯崔敏哲: JAERI-M 7757，(1978).

(45) YANG, J.Y., et al.: USNRDL-TR-471, (1960).

(46) MARTER, W.L.: DP-1369, (1974).

(47) Sutra-Fourcade, Y.: CEA-R-3350, (1967).

(48) Ballereau, P.: CEA-BIB-179, (1970).

(49) 原子力委貝会：発笔用原子炉施設の安全解析に関卞る军 象指轩, (1977)

50) OTADUY, P., et al.: CONF-760935-P4, (1976)

\section{ケ昭和 54 年度会費をお払込み願いますう \\ (䄇求费が必要な場合に注ご一㫰願います。)}

本公の公計年度は4月1日〜翌年3月31日です。会費は定款で全類前納となっておりますので，54年度会

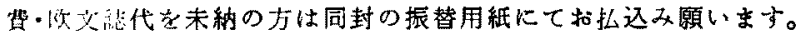

（10名以上分の全頼を上半期中に一括た払込み下されば $5 \%$ 引になります）

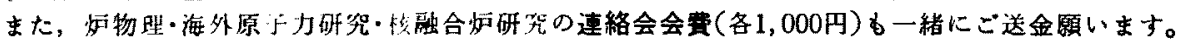

$$
\begin{aligned}
& \text { 正会员 } 5,000 \text { 円 学生会员 } 2,500 \text { 円 楚助会虽 } 1 \text { 口25, 000円( } 2 \text { 口以上) } \\
& \text { 「欧文誌」誌代 会員特価 2,000円 }
\end{aligned}
$$

会督を滞納されると，年全・分科会の口頭発表申込みや「会誌」投稿等は受け付けません。上半期(4〜9月) 半年間滞納すると，10月号から「会誌」が発送保留となり(「欧文誌」代满納る同粎)，来年3月までの1年间 滞納すると「除名」になりますのて，こ留意願います。(除名の場合は，半年間既送分 6 冊の会誌代・欧文誌 代はそれぞれ定価( 800 円×6 冊＝4,800円）でお支払い頂きます。） 